\title{
Pakistan media: Unnamed sources reveal political crises and law and order problems
}

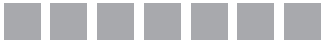 \\ Abhijit Mazumdar \\ UNIVERSITY OF tenNESSEE IN KNOXVILLE, USA \\ DOI: 10.19195/1899-5101.9.2(17).5
}

\begin{abstract}
Journalists use sources to accord credibility to their news stories. However, they use unnamed sources when they feel the sources would be harmed for revealing information to the media. This qualitative study analyzes news from unnamed sources in political stories in Pakistani media. It uses grounded theory to find common themes in the news obtained from unnamed sources. The common themes found in the study were about political crises, and breakdown of law and order in Pakistan. The author discusses the ways in which unnamed sources were used in the stories. Many unnamed sources gave views that were different from those given by named sources in the same story, while a few stories did not give any indication of the rank of the unnamed sources in the hierarchy of the political party or the army.
\end{abstract}

KEYWORDS: unnamed sources, Pakistan media, politics, politicians, army, themes.

\section{INTRODUCTION}

In news media, sources are "the actors whom journalists observe or interview, including interviewees who appear on air or who are quoted" (Gans, 1979, p. 80). Journalists use sources to accord objectivity and credibility to news stories (Zelizer, 1989). However, the audience considers journalists as biased when they give their own views in news reports (Reese, 1997). Therefore while choosing sources for news reports, journalists must follow newsroom routines, which includes named sourcing. Named sourcing allows the audience to verify information attributed to sources in news reports. Journalists can be held accountable for choosing sources for news reports by comparing with sources used in news reports of other media organizations. Allen (2008) associated media transparency with credibility. He, however, cautioned that transparency and credibility are not necessarily linked to each other. He argues that media organizations should adopt greater transparency, for instance attributing information to sources in news reports. However, he cautions that audiences may not react with more trust even if news is at- 
tributed to sources (Allen, 2008). With unnamed sourcing the audience is less able to determine the authenticity of sources quoted in news stories. The withholding of the identity of a news source may not allow the audience to verify information (Bell, 1991).

Oftentimes journalists have to protect their sources from harm if they believe the sources would face retribution for revealing information to media (Gilson, 2003). In such cases journalists do not identify their sources in news reports. Many news organizations have strict norms for using unnamed sources. For instance, the Associated Press allows the use of unnamed sources only if the news cannot be obtained from elsewhere, is independently verified, and the reporter's superiors, to whom the identity of the source has been revealed, agree to their use. In order to enhance media credibility, the news agency has made it mandatory that its journalists explain in their news reports why the source requested anonymity (Associated Press, 2013).

Three factors have an impact on source-journalist relationships. The first is source availability, which is the degree to which governmental and non-governmental sources are available to reporters. Government officials are the most available sources to journalists because of their frequent interactions with them (Gans, 1979). The second is journalists' objectivity, which makes journalists evaluate credibility of news sources they plan to quote in their news stories (Meyer, 1988). The third is context, which consists of news events, their causes and consequences (Findahl \& Hoijer, 1985). However, the use of unnamed sources denies the audience the benefit of knowing about the availability of the source, objectivity of the use of the source, and the relation of the source with the news event about which the source has provided information. The term anonymous sources has often referred simultaneously to both full and partial anonymity in academic research. It has also been used interchangeably with the terms unnamed sources (e.g. Adams, 1962), veiled sources (e.g., Culbertson, 1975), and confidential sources (e.g. Strupp, 2005). This paper researches qualitatively for common themes obtained from news given by unnamed sources in political news stories in Pakistani media. The study uses grounded theory to analyze news from unnamed sources.

\section{LITERATURE REVIEW}

\section{Unnamed sourcing for news}

The motives for news sources seeking anonymity from journalists vary considerably (Hess, 1996) from testing audience reaction to policies (Tuchman, 1978) to enhancing a journalist's reputation (Keat, 2005). Strupp (2005) deplored news media for granting anonymity too easily to sources demanding it. Use of unnamed sources in news reports makes audiences suspect the credibility of journalists (Sternadori \& Thorson, 2009). Those in support of using unnamed sources, however, say 
that if information could not be attributed to unnamed sources important news will not reach the audience (Hoyt, 2009). According to Duffy and Freeman (2011), anonymity should not be given to sources while reporting about law enforcement investigations in which no charges have been filed against suspects, routine business and finance news, early announcements of public events and routine information from governmental organizations. According to Boeyink (1990), before promising anonymity to a source, journalists should adhere to the following guidelines: 1) Authorization for promises of anonymity to a source must come from editors, 2) Anonymity should be granted only if a cause is in the public interest, 3) Reporters should use anonymity only as a last resort, 4) Reasons for granting anonymity must be given in news stories. Sources should be as fully identified as possible in news reports to enhance credibility, 5) Benefits of using an unnamed source should be considered against potential pitfalls, 6) Anonymity should not be granted unless intentions of the source are just, and 7) News obtained from an unnamed source must be verified from a second source to ensure credibility for the reporter and the media organization.

Shoemaker and Reese (1996) suggested that many factors have an impact on news content reaching the audience, such as organizational constraints and ideology of journalists. Journalists depend on official sources for getting news (Sigal, 1973). Selection of news sources has an impact on the way news is portrayed among the audience (Speckman \& Bichler, 1999). Pjesivac and Rui (2014) found that people in the U.S. and China rated news stories that used named sources more credible than those using only anonymous sources. However, Zhang (2011) found anonymous sources were widely used in news reports in China. The analysis of 100 stories that turned out to be false and those that had appeared in Chinese media between 2001 and 2010 showed that $50 \%$ of them had only unnamed sources to provide news (Zhang, 2011). This brings the focus on credibility of unnamed sources in reporting. Meyer (1988) found that credibility of a news source depended on five factors: fairness, bias, accuracy, trustworthiness, and comprehensiveness. However, the use of unnamed sources damages source credibility among the audience because the audience will not be able to verify news presented to them (Meyer, 1988).

Journalistic credibility was damaged when stories using unnamed sources were later found inaccurate (Shepard, 1994). For instance, Newsweek in 2005 published a news report based on only one unnamed military source in the U.S. (Seelye \& Lewis, 2005). The magazine reported that an American military official at the Guantanamo Bay detention center had shown disrespect to the Koran, the religious book of Muslims. The magazine later retracted the article on the grounds that the publication was trying to verify whether the report was true. The editors of the magazine later admitted that the news report was based on only one source even though the report had cited many military sources (Seelye \& Lewis, 2005). Government officials avoid scrutiny of their actions when journalists use them as anonymous sources in news reports (Kurtz, 2010). According to Hallin, Manoff and 
Weddle (1993), anonymous sources were extensively used in news reports about national security in major dailies. As many as $48 \%$ of executive branch sources and $32 \%$ of sources in the U.S. Congress went unnamed in these news reports. Unnamed sourcing has been a common practice in war coverage (Denham, 1997), network news (Wulfemeyer \& McFadden, 1986) and magazines providing news (Wulfemeyer, 1985). According to Martin-Kratzer and Thorson (2007), overall there was a decline in the use of unnamed sources by journalists in wire and staffproduced stories and among all circulation categories in the U.S. in 2004 compared with 2003. Although a few studies show that use of unnamed sources increased in the early 1980s (e.g. Wulfemeyer, 1985), the practice was not much in use after Janet Cooke's fabrication of a heroin addict led to the withdrawal of the Pulitzer Prize awarded to her (e.g. Duffy \& Freeman, 2011). While a lot of quantitative research data is available on unnamed sourcing, few studies have qualitatively researched news obtained from unnamed sources in media.

\section{MEDIA AND GOVERNMENT IN PAKISTAN}

Pakistan has witnessed long periods of military rule alternating with democracy since the time of its creation in 1947 (Hashim, 2013). The state of Pakistan has from time to time witnessed political turmoil both at the level of state and federal governments. For instance, then Pakistan President Pervez Musharraf sacked the chief justice of the Supreme Court of Pakistan, triggering a crisis (Wilkinson, 2007). The relations between the government of Pakistan and its media have often been turbulent. At times the government of Pakistan has tried to control the press with arrests of journalists and canceling the license of newspapers. During the military dictatorship of Gen. Zia-ul-Haq the country witnessed a lot of press censorship through what came to be known as the press advice system: any violation of rules laid out by the Pakistan government was to be punished with a prison term of up to 10 years and payment of a fine (Pakistan, 2015a). Prime Minister Nawaz Sharif too tried to influence the press to not write against him. The media in Pakistan nonetheless continued reporting about widespread abuse of power during his reign (Pakistan, 2015a).

Despite democratically elected governments in power, the Pakistan army continues to exert influence on the country's politics (Khan, 2015). The army has often been accused of illegally detaining and killing journalists who have tried to expose its wrongdoings (Jalal, 2014). For instance, noted Pakistani journalist Hamid Mir alleged that the Inter-Services Intelligence or the ISI, which is a secret service affiliated with the Pakistan Army, had tried to kill him (Hamid Mir..., 2014). The people of Pakistan favorably look upon their country's army with over $87 \%$ of them appreciating the services the army has rendered Pakistan (Pew Research Center, 2014). However, the role of Pakistan's army in the country's politics cannot be ignored. Pakistan has had over 20 years of military dictatorship, after the army overthrew democratically elected civilian governments (Hashim, 2013). According to 
Freedom House ratings the press in Pakistan is not free. It gave the country a press freedom score of 65 on a scale of $0-100$, where 0 symbolized free press and 100 meant a country with no press freedom. Similarly, Freedom House ranked Pakistan low on political freedom with a score of 30 on a scale of $0-40$, where a score of 0 meant a nation with full political freedom while 40 symbolized no political freedom (Pakistan, 2015b).

Besides governmental control, print media in Pakistan has Press Council of Pakistan guidelines to adhere to. The Press Council of Pakistan was set up in 2002 to act as a watchdog over the print media and uphold ethical standards in journalism in the country. It has journalists, government officials and elected representatives of the country as its members. Many vacant positions within the Press Council of Pakistan are yet to be filled up, hampering the organization's work (Haq, 2014). The Press Council of Pakistan arbitrates cases of breach of media ethics, but can only recommend action against an erring newspaper. It cannot enforce its decisions (Press Council..., 2002). Its guidelines are relevant for more than 1,500 newspapers and journals existing in Pakistan. Among those newspapers and journals, the Dawn is the largest selling English-language newspaper in the country with a circulation of 675,000 copies each day (World Association of Newspapers and News Publishers, 2015).

\section{METHODOLOGY}

\section{Sample}

To study the use of unnamed sources in Pakistan political reporting, the Englishlanguage Pakistani newspaper Dawn was chosen. The study period was from January 1, 2014 to December 31, 2014. A reason why this year-long period was chosen for the study was because Pakistan witnessed political turmoil in 2014, with Prime Minister Nawaz Sharif facing regular street protests from members of the political party, Tehreek-i-Insaaf, over rigged elections. The Pakistan army was alleged to be stoking the street protests to maintain its own grip over politics in Pakistan (Siddiqui, 2014). Besides political crisis, the nation witnessed a massacre of children as the terrorist outfit Taliban carried out an attack on a school killing 141 children in 2014 (BBC, 2014). The Pakistan Muslim League-Nawaz (PMLN) is the political party in power in Pakistan (Nawaz sworn..., 2013), while Pakistan People's Party (PPP) is the main opposition party in the country (PPP's Khursheed..., 2013). For the study three entities were chosen: PMLN, PPP and Pakistan army.

The author conducted LexisNexis Academic searches with the search term PMLN in the headline AND the search terms given in Appendix 1. Similar searches were conducted for the Pakistan People's Party with the search term PPP in the headline AND the search terms given in Appendix 1. Also, a search was conducted with the search term army in the headline AND the search terms given in Appendix 1. 
In all, 107 stories were returned by the searches. After removing duplicates, the author was left with 101 stories to study the use of unnamed sources in political reporting in Pakistan. All article types (i.e., reports, features, editorials) were included in the study.

\section{Data analysis}

Grounded theory was used to understand broad themes obtained from quotes by unnamed sources in the political news stories included in the study. The unit of analysis was a story, because reading each news story in the sample was necessary to understand the context of news obtained from unnamed sources in the stories. The present study included both direct quotes as well as paraphrased ones from unnamed sources. In a three-step process, the author used open and axial coding to identify sub-themes, which later merged into major themes obtained in the third and final stage: selective coding. The author used open coding to set up categories for issues present in the quotes from unnamed sources in the sample (Corbin \& Strauss, 2008).

The next step was to identify sub-themes appearing in the categories obtained using open coding of the news stories in the sample. In the next stage called axial coding the sub-themes obtained from open coding were compared with each other. During this stage the author once again read the quotes from unnamed sources in the news stories included in the study. To understand the context of news obtained from the unnamed quotes, the author had to once again read the entire stories that had the unnamed quotes. A framework was set up to analyze the quotes from unnamed sources using the constant comparison method that involved comparing and contrasting sub-themes that were obtained from quotes from the unnamed sources in the sample (Corbin \& Strauss, 2008). The third stage, called selective coding, involved elaborating on major themes emerging from axial coding of quotes from unnamed sources (Corbin \& Strauss, 2008).

At this stage the author once again conducted a reading of the quotes from unnamed sources to understand the sense each unnamed quote appearing within a specific theme conveyed. The author then began to quote examples from the news stories in the sample to build on the themes already set up for the study. The author presented two major themes coming out of the study: 1) Political crises, 2) Breakdown of law and order.

\section{POLITICAL CRISES}

The themes for this section emerging from news obtained from anonymous sources related to lack of intra-party democracy, power struggle among political parties, and problems facing political parties. 


\section{Lack of intra-party democracy}

The unnamed quotes brought to the fore the issue of lack of intra-party democracy in Pakistan's political parties. The unnamed sources pointed to the fact that there was lack of intra-party democracy both at the state and national levels among political parties. The unnamed sources blamed their political leaders for not listening and addressing grievances of the workers of political parties and imposing their chosen candidates in positions of power within political parties without consulting local leaders about the compatibility and qualities of those nominated to positions of power.

Despite its claim of playing a big role in advancement of democracy in the country the party had always nominated office bearers without taking the workers into confidence. (Bacha, 2014)

The unnamed sources also spoke of how the committed cadre of political parties was moving away to other political outfits due to indifference of their party leaders to their grievances.

The workers were ignored during the last five-year tenure of the PPP (Pakistan People's Party). Due to the indifference of the party leadership, many old and committed workers left the party and joined PTI. (Yasin, 2014)

While in some cases the unnamed sources named political leaders from a city or state who benefitted most from lack of intra-party democracy, they did not name the national leaders of their parties, for instance, the chief of Pakistan People's Party, Bilawal Bhutto. The unnamed sources instead chose to use terms such as senior leaders and party leadership while blaming senior political leaders, especially, the chief of their political party, for taking decisions without consulting party workers.

\section{Power struggle among political parties}

Unnamed sources were used to bring to the fore the moves political parties made to grab positions of power both in the state and federal governments. The unnamed sources revealed how politicians were involved in secret negotiations with leaders of other political parties over issues of coalition tie-ups during elections and distributing public offices among themselves as coalition partners after elections were over.

After refusal by the PML-N to give the all-important water and power ministry to the JUI-F, the religious party put forth the demand for the ministry of housing and works. (Wasim, 2014)

The unnamed sources also revealed possible strategies that their party leaders would employ to outmaneuver their rivals from other political parties. 
The Chaudhrys have advised the PAT chief against opening too many political fronts at a time and to focus on their common foe, the PML Nawaz. (Butt, 2014)

The official narrative given by spokespersons of political parties and senior political leaders was at variance with the nature of information obtained from the unnamed sources. The named sources tried to either play down or deny behindthe-scenes negotiations or strategies being considered to outdo political opponents. The unnamed sources most often were not identified by their hierarchy in their political party nor was any indication given about the extent of their involvement in the decisions that they were talking about.

\section{Problems facing political parties}

The news obtained from unnamed sources pointed to the problems that political parties were facing both in conducting the daily functioning of the party and managing the administration of the country and states where their leaders were part of the government.

Senator Babar and Aurangzeb Barki had specially come to seek suggestions from the party's annoyed people. (PPP committee..., 2014)

The unnamed sources talked about various factions within their political parties headed by local politicians that were denting the image and credibility of the political party among the people of Pakistan. The unnamed sources also spoke of efforts that were being undertaken by the national leadership of their political parties to stop infighting and factionalism within their political outfit. While referring to infighting within a political party, the unnamed sources would name only local politicians who were opposing each other in a city or state. If the blame was to be attributed to the national chiefs of political parties, the unnamed sources would only use vague references such as "senior leaders". Oftentimes an unnamed source would use words such as "annoyed" to describe the rift among politicians belonging to a political party. Unnamed sources leveled allegations of corruption against politicians belonging to their political party, which were never spoken about by named sources belonging to the same political party.

We informed the committee that Zulfiqar Ali Bhutto and Benazir Bhutto used to hold workers' conventions and solve problems of the people, but at present party ministers have focused only on accumulation of wealth and have no sympathies with the party. (PPP committee..., 2014)

\section{Breakdown of law and order}

Unnamed sources in Pakistani media portrayed a breakdown of law and order in the country and the role of the Pakistan army in maintaining the unity and integ- 
rity of the country. These sources painted the Pakistan army in a positive light. The themes emerging for this section relate to terrorism gripping Pakistan, the role of the Pakistan army against terrorist organizations and the role of the army as a stabilizing factor in the politics of the country.

\section{Pakistan in the grip of terrorism}

The unnamed sources in the news reports included in the study described how terrorism was gripping Pakistan. They gave details of incidents of attacks on soldiers of the Pakistan army. The unnamed sources attributed many attacks as well as aborted attacks to terrorists, whom they termed militants. However, police officers quoted in the same news reports did not attribute the attacks to militants. Many times unnamed as well as named sources used the term militants interchangeably with terrorists. At times, only unnamed sources were used in news reports to inform people about the details of attacks by terrorists, for instance, the camouflaged dresses terrorists wore, the languages they spoke and most importantly, the accusations of being supporters of the U.S. they hurled at their victims. However, the named sources quoted in the same stories presented fewer facts about the attacks, oftentimes refusing to divulge details saying that the attacks were under investigation.

The attackers were speaking Urdu, Pashto and Shina languages and also accused the policemen of being the puppets of America. (Terrorists in..., 2014)

Unnamed sources attributed attacks leading to the death of army officers to militants or assailants while killings of civilians were attributed to robbers and miscreants. The unnamed sources portrayed the Pakistani state as one in the grip of terrorism, while the named sources in the same stories played down the significance of terrorism and gave the impression that the Pakistan government was in control of the situation in the country.

\section{Pakistan army fighting against terrorism}

The unnamed sources in Pakistani news stories portrayed the Pakistan army as a savior of the country. It depicted the army at the forefront of fighting terrorism and protecting the integrity of the country. The unnamed sources in the news reports included in the study never mentioned the defeats or temporary setbacks the army suffered. The army was portrayed as a victorious fighting unit that defeated terrorist groups in the terrorist-infested regions of Pakistan. The unnamed sources pointed out how the army had taken control of territories within Pakistan that were once considered bastions of terrorism. 
During the first stage of the operation, the main towns of Mirali, Miramshah, and Datta Khel, once considered militant's strongholds, and the roads connecting the towns had been cleared. (Operation..., 2014)

The unnamed sources also gave the number of terrorists killed by the Pakistan army. However, there was no named source in such stories to verify the actual number of terrorists killed by the Pakistan army. The unnamed sources did not name any individual officer of the armed forces as responsible for success or failure of army operations against terrorists. They also portrayed a consensus of opinion between the political leadership of Pakistan and its army regarding counter-terrorism operations.

The political consensus against terrorism and the unanimity of views between the political and military leadership were noted with satisfaction at the meeting. (Syed, 2014b)

\section{Pakistan army's role in country's politics}

The unnamed sources portrayed the Pakistan army as a stabilizing force in the fractious politics of the country. They pointed to the role of the army as a mediator among the political party in power and the main opposition party in the country. The army was shown to be a bulwark against political anarchy in the country and a guarantor of deals the political parties arrived at with each other. The unnamed sources also said that political parties opposing the government had trust in the army, but not in the political party running the government.

The protesting parties had a deep-rooted mistrust of the government and were not ready to trust them. Therefore, the army would guarantee the implementation of any agreement between the two sides. (Syed \& Khan, 2014)

The unnamed sources also brought to the fore how the political leadership of the country had turned to the army to provide security to people in areas where opposition political parties were carrying out protest demonstrations against the country's government. The army was depicted as having no interest in playing an active role in the country's politics though it was supposed to mediate disputes between political parties and maintain law and order in the country. The army was portrayed as being subservient to the civilian government in Pakistan, while expressing concern over security matters to the Pakistan government whenever need arose. The unnamed sources recounted how the army was restrained in expressing its anguish to the federal government over repeated Taliban terror attacks in the country by describing army commanders' reactions as "deep concern". The army was shown to be always prepared to ward off any attack within the country and attacks emanating from outside of Pakistan. The unnamed sources depicted the army as being on the same side of the Pakistan government in matters of defending the country; the army's job is to remain operationally prepared (Syed, 2014a). 


\section{CONCLUSIONS}

The unnamed sources depicted Pakistani politicians fighting for power and not interested in ushering in intra-party democracy. The Pakistan army, however, was portrayed as a force that was holding together the nation by fighting terrorism and stabilizing the politics of the nation. A Pew survey in Pakistan found that $93 \%$ of people considered terrorism a major problem in the country (Wike, 2013). The Pakistan army's fight against terrorism may have been a cause for its popularity in the country. The people of Pakistan favorably look upon their country's army with over $87 \%$ of them appreciating the services the army has rendered Pakistan (A less..., 2014). The depiction of the Pakistan army as a stabilizing factor in the country runs counter to the fact that since its creation in 1947, Pakistan has had over 20 years of military dictatorship, after the army overthrew democratically elected civilian governments (Hashim, 2013).

A reason why unnamed sources may not have revealed their identities is because of threats to their lives as well as to those of journalists reporting on the army. According to Jalal (2014), the Pakistan army is known to have killed journalists who wrote against them. Noted Pakistani journalist Hamid Mir had attributed an assassination attempt on him to the Pakistani spy agency Inter-Services Intelligence, which is affiliated to the Pakistan Army. He alleged that the Pakistan army was angry with his coverage of the army putting down a revolt in Balochistan province of Pakistan (Hamid Mir..., 2014). According to Freedom House, the Pakistani press is not free and the country scores low on political freedom (Pakistan, 2015b). Lack of political and press freedom means that few Pakistani politicians would like to criticize their leaders and few journalists would be willing to write against Pakistani politicians and the army. Pakistan's former foreign minister H.R. Khan acknowledged the fact that the Pakistan Army plays a major role in the country's politics, reducing the powers of democratically elected governments in the country (Khan, 2015).

The unnamed sources in this study criticized politicians for problems that the political parties were facing and for refusing to bring democracy and transparency to political parties. The critical views of the unnamed sources in Pakistan media are similar to what the people of Pakistan have of their country's politicians. According to a Gallup survey, $81 \%$ of the people of Pakistan saw widespread corruption in the federal government while only $28 \%$ of the people approved of the federal government (Pakistan's troubled..., 2015).

Among the news reports included in the study, two stories were based only on unnamed sources. No named source was quoted in the two stories. Pjesivac and Rui (2014) found that people in the U.S. and China considered stories based only on unnamed sources as less credible than stories where sources were identified. Smith (2007) found that people accepted unnamed sources in stories dealing with governmental wrongdoings, but not in news reports about the personal lives of 
public officials. Brown et al. (1987) found that news reports about the military used many unnamed sources than news reports on any other issue. Senior U.S. journalist Bob Woodward argued that the Watergate coverage that led to then U.S. President Richard Nixon's resignation would not have happened without unnamed sources providing journalists with valuable information (Shepard, 1994). A possible explanation for the use of unnamed sources in countries apart from the U.S. is that sources may be more likely than U.S. citizens to expect being granted anonymity due to deficiencies in the media landscape in underdeveloped countries and those with relatively new democratic governments. For instance, according to Pehe (2005), Czech reporters are more susceptible than U.S. journalists to political manipulation and grant anonymity to sources far more than U.S. journalists. While many stories in the study used the term "sources said" to describe unnamed sources, the frequency of such vague descriptions has caused concern among journalists.

The cryptic phrase "sources said" will never again be the sole attribution for a story in Newsweek, wrote the magazine's editor-in-chief Richard M. Smith in a letter to the readers. (Kurtz, 2005)

In many news stories in the study, the unnamed sources gave views that were different from named political sources quoted in the same story. This may have been because the named sources did not want to invite retribution from senior leaders of their political parties. For instance, Imran Khan, the chairman of the political party Tehreek-i-Insaaf, threatened to sack leaders from his party if they were to speak to journalists about the internal affairs of the party (Haider, 2015). Most reports in the present study did not identify the unnamed sources with their hierarchy within their political party nor did the stories mention why the sources sought anonymity. Also, it was not stated in the news reports whether the unnamed sources were themselves involved in making decisions about which they were providing information to the media. According to Boeyink (1990), unnamed sources should be identified as far as possible with their hierarchy or position. While studying common themes obtained from anonymous sources in Indian political reports, Mazumdar (2015) found that the themes focused more on weaknesses, style of functioning of politicians and power centers within political parties. However, Mazumdar's (2015) study did not result in the Indian army being part of the themes. A reason for this could be that the Indian army does not interfere in the politics of the country. However, the themes in the present research focus more on problems of political parties and the army's role in politics and defense of Pakistan.

\section{REFERENCES}

Adams, J.B. (1962). The relative credibility of 20 unnamed sources. Journalism Quarterly, 39, pp. $79-82$. 
Allen, D.S. (2008). The trouble with transparency. Journalism Studies, 9 (3), pp. 323-340.

Associated Press. (2013). AP news values and practices. Retrieved November 1, 2015 from www. ap.org/company/news-values.

Bacha, A.H. (2014, May 5). Reorganization of PPP and the decreasing role of workers in KP. Dawn. Retrieved November 3, 2015 from http://www.dawn.com/news/1104259.

Bell, A. (1991). The Language of News Media. Oxford, UK: Blackwell.

Boeyink, D.E. (1990). Anonymous sources in news stories: Justifying exceptions and limiting abuses. Journal of Mass Media Ethics, 5 (4), pp. 233-246.

Brown, J.D., Bybee, C.R., Wearden, S.T., Straughan, D.M. (1987). Invisible power: Newspaper news sources and limits of diversity. Journalism Quarterly, 64 (1), pp. 45-54.

Butt, W.A. (2014, October 9). Chaudhrys play 'peacekeepers' in PPT-PAT media war. Dawn. Retrieved November 8, 2015 from http://www.dawn.com/news/1136721.

Corbin, J.M., Strauss, A.L. (2008). Basics of Qualitative Research: Techniques and Procedures for Developing Grounded Theory (3rd ed.). Los Angeles, CA: Sage.

Culbertson, H.M. (1975). Veiled News Source - Who and What Are They? Washington, DC: ANPA News Research Center Study.

Denham, B. (1997, March). Journalists and official sources. A study of three news organizations across two periods of military conflict. Paper presented at the Southeast Colloquium of the Association for Education in Journalism and Mass Communication, Knoxville, Tennessee.

Duffy, M.J., Freeman, C.P. (2011). Anonymous sources: A utilitarian exploration of their justification and guidelines for limited use. Journal of Mass Media Ethics, 26 (4), pp. 297-315.

Findahl, O., Hoijer, B. (1985). Some characteristics of news memory and comprehension. Journal of Broadcasting \& Electronic Media, 29, pp. 379-396.

Gans, H.J. (1979). Deciding What's News: A Study of CBS Evening News, NBC Nightly News, Newsweek and Time. New York, NY: Pantheon Books.

Gilson, L. (2003). Trust and the development of health care as a social institution. Social Science and Medicine, 56 (7), pp. 1453-1468.

Haider, I. (2015, August 5). Imran Khan threatens to sack party members who spill beans to media. Dawn. Retrieved November 1, 2015 from http://www.dawn.com/news/1198368.

Hallin, D.C., Manoff, R.K., Weddle, J.K. (1993). Sourcing patterns of national security reporters. Journalism Quarterly, 70 (4), pp. 753-766.

Hamid Mir blames ISI within ISI for attack. (2014, April 28). Dawn. Retrieved October 25, 2015 from http://www.dawn.com/news/1102478/hamid-mir-blames-isi-within-isi-for-attack.

Haq, R. (2014, September 20). Rudderless: Press Council of Pakistan, a name with no faces. The Express Tribune. Retrieved October, 25, 2015 from http://tribune.com.pk/story/764674/rudderless-press-council-of-pakistan-a-name-with-no-faces/.

Hashim, A. (2013, April 30). Pakistan: a political timeline. Al Jazeera. Retrieved October 24, 2015 from http://www.aljazeera.com/indepth/interactive/2012/01/20121181235768904.html.

Hess, S. (1996). News and News Making. Washington, D.C.: The Brookings Institute.

Hoyt, C. (2009, March 22). Those persistent anonymous sources. The New York Times. Retrieved October 15, 2015 from http://www.nytimes.com/2009/03/22/opinion/22pubed.html.

Jalal, A. (2014). The Struggle for Pakistan: A Muslim Homeland and Global Politics. Cambridge, MA: Belknap.

Keat, J. (2005, October). Unmasking the source. American Journalism Review. Retrieved October 27, 2015 from http://ajrarchive.org/Article.asp?id=3982.

Khan, O.F. (2015, December 18). Military still plays a bloated role in Pakistan politics: Hina Rabbani Khar. Times of India. Retrieved December 24, 2015 from http://timesofindia.indiatimes.com/ world/pakistan/Military-still-plays-a-bloated-role-in-Pakistans-politics-Hina-Rabbani-Khar/ articleshow/50236719.cms. 
Kurtz, H. (2005, May 23). Newsweek curbs unnamed sources. Washington Post. Retrieved October 24, 2015 from http://www.washingtonpost.com/wp-dyn/content/article/2005/05/22/AR20 05052200864.html.

Kurtz, H. (2010, June 15). Don't use my name: The anonymity game. Washington Post. Retrieved October 24, 2015 from http://www.washingtonpost.com/wp-dyn/content/article/2010/06/15/ AR2010061501315.html.

Martin-Kratzer, R., Thorson, E. (2007). Use of anonymous sources declines in U.S. newspapers. Newspaper Research Journal, 28 (2), pp. 56-70.

Mazumdar, A. (2015). Common themes in news from anonymous sources in Indian political reporting. Journal of Global Communication, 8 (2), pp. 105-113.

Meyer, P. (1988). Defining and measuring credibility of newspapers: Developing an index. Journalism Quarterly, 65, pp. 567-574.

Nawaz sworn in as PM (2013, June 5). Dawn. Retrieved November 2, 2015 from http://www.dawn. com/news/1016265.

Operation to be extended to remote areas: Army chief (2014, September 11). Dawn. Retrieved December 2, 2015 from http://www.dawn.com/news/1131244.

Pakistan. (2015a). Press Reference. Retrieved November 10, 2015 from http://www.pressreference. com/No-Sa/Pakistan.html.

Pakistan. (2015b). Freedom House. Retrieved November 10, 2015 from https://freedomhouse.org/ report/freedom-press/2015/pakistan.

BBC. (2014, December 16). Pakistan Taliban. Retrieved November 10, 2015 from http://www.bbc. com/news/world-asia-30491435.

Pakistan's troubled state. (2015). Gallup. Retrieved November 28, 2015 from http://www.gallup.com/ poll/157055/pakistan-troubled-state.aspx.

Pehe, J. (2005). Guard dog or yelping pup? A report on the state of Czech journalism. New Presence: The Prague Journal of Central European Affairs, 7 (2), p. 32.

Pew Research Center. (2013). On eve of elections a dismal public mood in Pakistan. Retrieved November 26, 2015 from http://www.pewglobal.org/2013/05/07/chapter-1-national-conditions-leaders-and-institutions/.

Pew Research Center. (2014, August 27). A less gloomy mood in Pakistan. Retrieved November 1, 2015 from http://www.pewglobal.org/2014/08/27/a-less-gloomy-mood-in-pakistan/.

Press Council to implement 17-point ethical code of practice. (2002, October, 29). Dawn. Retrieved December 1, 2015 from http://www.dawn.com/news/63999/press-council-to-implement17-point-ethical-code-of-practice.

Pjesivac, I., Rui, R. (2014). Anonymous sources hurt credibility of news sources across cultures: A comparative experiment in America and China. International Communication Gazette, 76 (8), pp. 641-660.

PPP committee, annoyed workers discuss intra-party elections. (2014, October 10). Dawn. Retrieved November 1, 2015, from http://www.dawn.com/news/1137053.

PPP's Khursheed Shah declared leader of opposition in NA. (2013, June 7). Dawn. Retrieved November 20, 2015 from http://www.dawn.com/news/1016699.

Reese, S. (1997). The news paradigm and the ideology of objectivity: A socialist at the Wall Street Journal. In: Berkowitz, D. (ed.). Social Meanings of News: A Text-Reader. Thousand Oaks, CA: Sage Publications, pp. 420-440.

Seelye, K.Q., Lewis, N.A. (2005, May 17). Newsweek retracts account of Koran abuse by U.S. military. The New York Times. Retrieved November 20, 2015 from http://www.nytimes.com/2005/05/17/ politics/17koran.html. 
Shepard, A. (1994, December). Anonymous sources. American Journalism Review. Retrieved November 20, 2015 from http://www.ajr.org/Article.asp?id=1596.

Shoemaker, P.J., Reese, S.D. (1996). Mediating Media Message: Theories of Influence on Media Content. New York, N.Y.: Longman.

Siddiqui, T. (2014, August 27). Pakistan faces a major political crisis: 6 things to know. The Christian Science Monitor. Retrieved November 20, 2015 from http://www.csmonitor.com/World/AsiaPacific/2014/0827/Pakistan-faces-a-major-political-crisis-6-things-to-know.

Sigal, L.V. (1973). Reporters and Officials: The Organization and Politics of News Making. Lexington, MA: D.C. Heath and Company.

Smith, R.F. (2007). Impact of unnamed sources on credibility not certain. Newspaper Research Journal, 28 (3), pp. 8-19.

Speckman, K.R., Bichler, L.A. (1999). Coverage of Mars exploration: Media messages about women scientists. Paper presented at the annual convention of AEJMC in New Orleans, L.A. Retrieved November 25, 2015 from http://files.eric.ed.gov/fulltext/ED433572.pdf.

Sternadori, M.M., Thorson, E. (2009). Anonymous sources harm credibility of all stories. Newspaper Research Journal, 30 (4), pp. 54-66.

Strupp, J. (2005). Losing confidence. Editor \& Publisher. Retrieved November 25, 2015 from http:// www.editorandpublisher.com/news/losing-confidence/.

Syed, B.S. (2014a, March 21). Army may keep out of dialogue committee. Dawn. Retrieved November 25, 2015 from http://www.dawn.com/news/1091764.

Syed, B.S. (2014b, December 26). Army starts groundwork for setting up courts. Dawn. Retrieved November 25, 2015 from http://www.dawn.com/news/1153246.

Syed, B.S., Khan, I.A. (2014, August 30). Govt on back foot as army looks to continue 'mediation.' Dawn. Retrieved November 25, 2015 from http://www.dawn.com/news/1128729.

Terrorists in army uniform storm police station in Diamer. (2014, July 5). Dawn. Retrieved November 25, 2015 from http://www.dawn.com/news/1117218.

Tuchman, G. (1978). Making News: A Study in the Construction of Reality. New York: Free Press.

Wasim, A. (2014, January 27). PML-N, JUI-F differ on portfolios. Dawn. Retrieved November 25, 2015 from http://www.dawn.com/news/1083016.

Wike, A. (2013). What Pakistan thinks. Pew Research Center. Retrieved November 25, 2015 from http://www.pewglobal.org/2013/05/10/what-pakistan-thinks/.

Wilkinson, I. (2007, March 17). Crisis for Musharraf over justice chief's sacking. The Telegraph. Retrieved November 20, 2015 from http://www.telegraph.co.uk/news/worldnews/1545843/ Crisis-for-Musharraf-over-justice-chiefs-sacking.html.

World Association of Newspapers and News Publishers. (2015). World press trends. Retrieved November 25, 2015 from http://www.wan-ifra.org/.

Wulfemeyer, K.T. (1985). How and why anonymous attribution is used in Time and Newsweek. Journalism Quarterly, 62 (1), pp. 81-86.

Wulfemeyer, K.T., McFadden, L.L. (1986). Anonymous attribution in network news. Journalism Quarterly, 63 (3), pp. 468-473.

Yasin, A. (2014, October 10). Disgruntled PPP workers refuse to attend Karachi public meeting. Dawn. Retrieved November 25, 2015 from http://www.dawn.com/news/1137040.

Zelizer, B. (1989). "Saying" as collective practice: Quoting and differential address in the news. Text \& Talk, 9 (4), pp. 369-388.

Zhang, T.F. (2011). Content analysis of Shanghai journalism review 2001 to 2010: Top 10 fake news. Retrieved November 25, 2015 from news.xinhuanet.com/zgjx/2011-04/06/c_13815607.htm. 


\section{APPENDIX 1}

A list of search terms used are given below.

PMLN - sources said, a source said, a senior leader said, an insider said, a PMLN leader said, a senior PMLN leader said, a senior party leader said, a senior party functionary said, a party functionary said.

PPP - sources said, a source said, a senior leader said, an insider said, a PPP leader said, a senior PPP leader said, a senior party leader said, a senior party functionary said, a party functionary said.

Army - sources said, a source said, an insider said, an officer said, a senior officer said, an army officer said, a senior army officer said. 